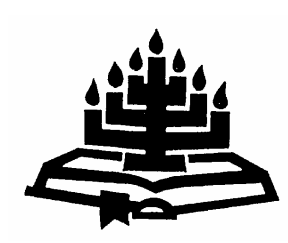

\title{
Jesus en demoonuitdrywing: 'n ondersoek na Jesus se hantering van demone volgens die Evangelies
}

\author{
F.P. Viljoen \\ Skool vir Bybelwetenskappe en Bybeltale \\ Potchefstroomkampus \\ Noordwes-Universiteit \\ POTCHEFSTROOM \\ E-pos: sbbfpv@puk.ac.za
}

\begin{abstract}
Jesus and exorcism: an investigation of Jesus' dealing with demons according to the Gospels

In view of present-day reports of demon-possession and often disputable practices of exorcism, a study is made of these phenomena in the Gospels. According to the Gospels demonpossession was a stark reality. Through his exorcistic activities Jesus demonstrated his absolute authority over Satan and his demons. Despite critical views that the devil, demons and exorcism form part of an outdated worldview, it is asumed in this article that demon activity is still a reality. A survey is made of Jesus' exorcism practices from two examples to identify the features of demonic cases apparent from these examples.
\end{abstract}

\section{Opsomming}

Jesus en demoonuitdrywing: 'n ondersoek na Jesus se hantering van demone volgens die Evangelies

In die lig van hedendaagse berigte van demoonbesetenheid en dikwels twyfelagtige praktyke van demoonuitdrywing, word 'n ondersoek gedoen na sodanige fenomene in die Evangelies. Volgens die Evangelies was demoon-besetenheid 'n wrede werklikheid. Met sy demoonuitdrywings het Jesus sy absolute gesag oor die duiwel en demone bewys. Ten spyte van kritiese standpunte dat die duiwel, demone en eksorsie deel vorm van 'n vergange wêreldbeeld, word daar in hierdie artikel aanvaar dat demoonaktiwiteit nog steeds 'n realiteit is. Jesus se eksorsie-aktiwiteite is aan die hand van twee voorbeelde 
ondersoek om kenmerke van demoniese gevalle te identifiseer soos dit uit hierdie voorbeelde blyk.

\section{Inleiding}

Sendelinge in Suid-Afrika berig dat hulle dikwels gekonfronteer word met 'n fenomeen wat soos demoon-besetenheid lyk. In gereformeerde kringe word daar in die algemeen kennis geneem van die bestaan en optrede van die duiwel en demone. Helaas bestaan daar heelwat vaagheid en dikwels wanpersepsies wanneer oor die duiwel en demone gepraat word. Te midde hiervan bestaan daar getuienis van jeugdiges (selfs sommiges met 'n kerklike agtergrond!) wat by okkultiese praktyke betrokke is. Sulke jongmense raak by gevaarlike aktiwiteite ingesleep met ontstellende gevolge, terwyl ouers radeloos voel en onseker is oor wat om onder sulke omstandighede te doen. Aan die ander kant word daar binne sommige evangeliese en charismatiese kringe soms opspraakwekkende, maar ook twyfelagtige uitsprake gemaak oor ervarings met demone en die uitdrywing daarvan.1 Bedenklike Skrifgebruik word soms aangewend om hieraan 'n teologiese basis te verleen (vgl. Janse van Rensburg \& Cilliers, 1998:34). Die gevaar bestaan ook dat vreemde en onverklaarbare gedrag van mense eenvoudig aan duiwelbesetenheid toegeskryf word (Gibbons, 2001:19; Strecker, 2002:117).

Die vraagstuk raak meer gekompliseerd met die herlewing van tradisionele Afrika-godsdienste met hulle geloof in towery en die inwerking van die geesteswêreld op die samelewing. Kontekstualisering van die Christelike geloof in Afrika kan maklik lei tot 'n sinkretisme, waar magie en die aktiwiteit van engele verwar word. Hierbenewens stimuleer spiritistiese filosofieë denke oor geestesaktiwiteite in die moderne samelewing (vgl. Vergeer, 2002:373). Hierteenoor bestaan daar sedert die epogmakende werk van Strauss (1846, herdruk in 1973) oor die mitiese aard van die wonderverhale van die Evangelies groot huiwering onder navorsers om te veel af te lei uit die wonders wat aan Jesus toegeskryf word. In die algemeen was die genesingsverhale minder moeilik om te aanvaar, maar wanneer dit by eksorsies as sodanig kom, word dit problematies vir diegene wat wetenskaplik met siekte wil omgaan.

1 Ouweneel (2003:185-186) bespreek 'n aantal sulke twyfelagtige ervarings waar "kankerdemonen" en "aidsdemonen" na bewering uit pasiënte gedryf is, waarna hulle gesond geword het. 
Die woorde van Bultmann (1953:5) word dikwels in dié verband aangehaal:

It is impossible to use electric light and the wireless and to avail ourselves of modern medical and surgical discoveries, and at the same time to believe in the New Testament world of demons and spirits.

Dunn noem hierdie tendens "The flight from dogma" (2003:25), die "exit (from) Revelation and miracle" deur die "scientific criticism" (2003:29) waarbinne onderskeid getref word tussen "historie" (historical om na rou historiese data te verwys) en "Geschichte" (historic "where Jesus is seen in his significance") (Dunn, 2003:49).

Onder moderne godsdienswetenskaplikes is 'n groeiende skeptisisme teen die bestaan van die engeleryk. Die engeleryk word beskou as deel van 'n primitiewe wêreldbeeld (Davies, 1995:93). Davies (1995:99) en Strecker (2002:117) staan dus skepties teenoor die Bybelse getuienis oor eksorsie, aangesien hulle meen dat die Bybelskrywers die "possession paradigm" volledig oorgeneem het. Du Plessis (2005:165) neig om die Satan en sy magte te beskou as behorende tot 'n vervloë mitologiese wêreldbeeld. In ander gevalle word huidige psigologiese (Goodman, 1988:15) en sosio-politiese (Guijarro, 2002:159) teorieë as modelle oorgeneem om berigte van demoonbesetenheid en bevryding te interpreteer. Pilch (2000:32) kategoriseer eksorsie as "symbolic healing", waar die siek persoon in kontak gebring word met die mitiese wêreld: "For instance, Peter's mother-in-law in the Luke account suffers form a demon named Fewer and therefore she can be treated by exorcism" (Pilch, 2000:33). Sodanige genesingsmetodes is slegs effektief "when they are taken literally and their symbolic identity is not recognized. When they are demystified, they tend to lose their effectiveness ... when demons are exorcised, the anxious client believes the cause of the problem is gone" (Pilch, 2000:35). Die geneser bevestig dan die pasiënt se vermoede en die sosiale omgewing bemoedig die bevryde persoon. Sodoende word die kognitiewe prosesse van angs gekalmeer.

In die lig van hierdie tendense ontstaan die vraag hoe Christene, wat getrou wil bly aan die boodskap van die Nuwe Testament, maar ook wil rekening hou met bevindings van die moderne wetenskap die eksorsie-verhale van die Nuwe Testament moet interpreteer. Hoort hierdie verhale by 'n primitiewe, voorwetenskaplike verstaan van siekte wat deesdae onaanvaarbaar is in die lig van die moderne mediese wetenskap? Of is die wêreldbeeld van die verhale nog 
geldig en bied dit 'n korrektief op die moderne wetenskaplike wêreldbeeld?

Te midde van hierdie vrae is dit sinvol om op 'n verantwoordelike manier opnuut weer aandag te gee aan die Bybelse getuienis oor die duiwel en demone. Dit is duidelik dat daar 'n behoefte bestaan aan antwoorde uit die Bybel oor hierdie vraagstuk. Die Bybel is in die gereformeerde teologie die riglyn vir die geloof en die praktyk.

Satan en sy magte is meer prominent in die Nuwe Testament as in die Ou Testament. Die hart van die Nuwe Testament is die verlossingwerk van Christus en die oorwinning van die Satan en sy magte: "Victory over Satan was the sign of the dawning of God's rule" (Guijarro, 2002:172). Dit is vanselfsprekend dat hierdie konfrontasie sou lei tot groter prominensie aan die aktiwiteite van die bose: "Die Allgewallt der Civitas Diaboli ist erschüttert. Die Civitas Dei muss im Anbruch sein!" (Stauffer, 1948:105).

Die doel van hierdie artikel is om vas te stel wat die Evangelies oor Jesus se hantering van die duiwel, demone, demoonbestenheid en eksorsie berig, deur op twee voorvalle te konsentreer waar berig word dat Jesus demone uitgedryf het. 2 Hierdie artikel vorm deel van 'n groter navorsingprojek waar die fenomeen van demoonbesetenheid in die lig van die Skrif bestudeer word.

\section{Begripsontleding}

In die Evangelies word 'n verskeidenheid woorde gebruik waarmee na demone en besetenheid verwys word. Louw en Nida (1989:136149) bespreek hierdie begrippe onder domein 12 (supernatural beings and powers). Daar bestaan dikwels verwarring oor terminologie wanneer daar oor die duiwel, demone en besetenheid gepraat word. Theron (2003:194-212) bespreek die kompleksiteit van begrippe wat binne die kerklike diens van bevryding van bose magte gebruik word. Sonder om hierdie kompleksiteit opnuut te hanteer, word die terme wat in hierdie artikel gebruik word, kortliks geïdentifiseer.

In die eerste plek moet daar onderskei word tussen die duiwel

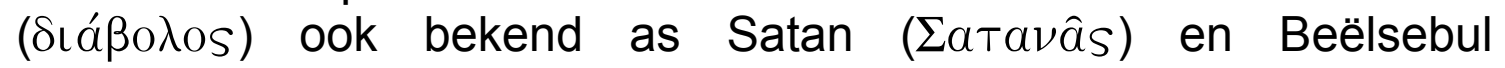

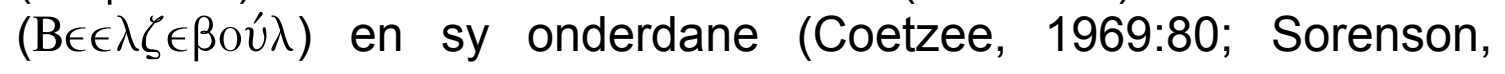

2 Om al die voorbeelde van eksorsie in die Evangelies in een artikel te bespreek, sal te omvangryk wees. 
2002:121). ${ }^{3}$ Die Satan is die hoof van die koninkryk van die bose (Langton, 1977:27). Die duiwel gebruik sy onderdane om mense te teister4 (Dunn \& Twelftree, 1998:178-179). Die volgende terme word in die Evangelies gebruik om na hierdie onderdane te verwys:

- Die term $\delta a i ́ \mu \omega \nu$ (demoon) kom net in Matteus 8:31 voor.

- $\Delta a \iota \mu o ́ v ı o v ~(v e r k l e i n w o o r d ~ v a n ~ d e m o o n)$ word meer as 50 keer in die Evangelies en Handelinge gebruik, teenoor slegs nege verwysings in die res van die Nuwe Testament. Matteus gebruik

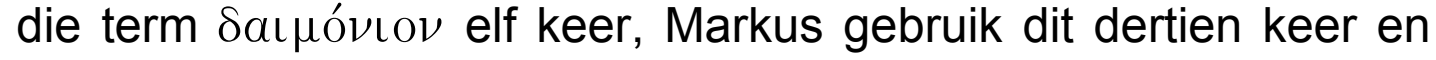
Lukas gebruik dit 22 keer in die Evangelie en een keer in Handelinge.

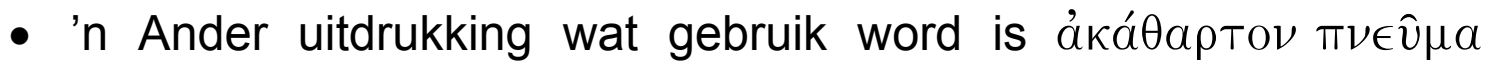
(onrein gees) ${ }^{5}$ wat 27 keer gebruik word. Matteus gebruik twee keer die byvoeglike naamwoord áká $\theta \alpha \rho T O S$ as beskrywing van 'n $\pi \nu \in \hat{v} \mu \alpha$, terwyl Markus dit elf keer gebruik en Lukas vyf keer in die Evangelie en twee keer in Handelinge.

- Die uitdrukking $\pi 0 \nu \in \rho o ́ s ~ \pi \nu \in \hat{v} \mu \alpha$ (bose gees) kom agt keer in die Evangelies en Handelinge voor, en oorwegend in Lukas en

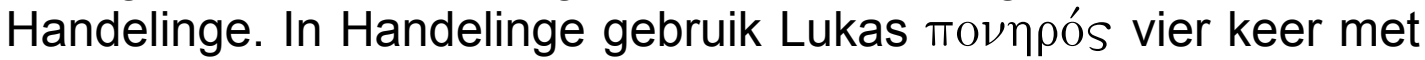
verwysing na 'n $\pi \nu \in \hat{v} \mu \alpha$.

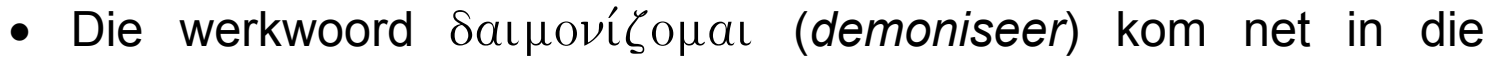
Evangelies voor. Dit word sewe keer deur Matteus gebruik, vier keer deur Markus, een keer deur Lukas en een keer deur Johannes.

Ander uitdrukkings wat gebruik word:

- $\pi \nu \in \hat{v} \mu \alpha a ̉ \lambda a \lambda o \nu$ (stom gees).

$3 \quad$ Langton (1977:26) illustreer hierdie gebrek aan onderskeiding wat selfs uit die

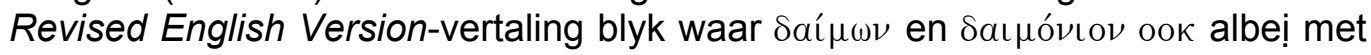
devil vertaal is.

$4 \quad$ Volgens sommige navorsers is die duiwelkonsep in die Nuwe Testament die produk van Babiloniese en Persiese invloed op die Joodse denkwêreld, en dat dit vandag as deel van 'n vergane wêreldbeeld beskou moet word (bv. Van Aarde, 1986:547). Hierteenoor is ander navorsers oortuig dat die ontkenning van sy bestaan juis die duiwel se grootste triomf is (bv. Möller, 1987:173 en Van Zyl, 1992:22).

5 "'Spirit' and 'demon' are more or less interchangeable in the synoptic Gospels" (Dunn \& Twelftree, 1998:179). 


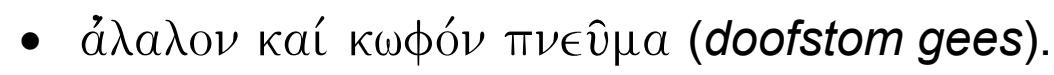

- Soms word die naamwoord $\pi \nu \in \hat{v} \mu \alpha$ (gees) sonder 'n adjektief gebruik, maar uit die konteks is dit duidelik dat 'n bose gees bedoel word.

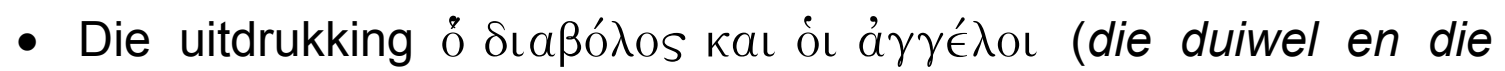
engele) word in Matteus 25:41 gebruik.

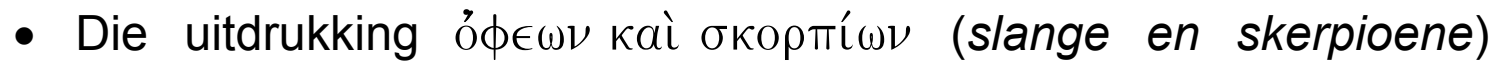
(Luk. 10:19) verwys waarskynlik ook na demoniese magte.

Anders as in die vroeëre Griekse literatuur, stel die Nuwe Testament demone nie gelyk aan die geeste van die dooies nie. Hulle word ook nie beskou as tussengangers tussen God en die mens nie. Laasgenoemde funksie word deur engele verrig (Sorensen, 2002:121).

Die verskeidenheid begrippe toon dat die Evangeliste 'n onderskeid maak tussen die duiwel en sy onderdane. Die duiwel gebruik die onderdane om mense in sy beheer te kry en op 'n verskeidenheid maniere ten kwade te beïnvloed.

\section{Die realiteit van demoonbesetenheid}

In die Evangelies (en Handelinge) word daar dikwels berig oor die aktiwiteit van demone en die magte van die duisternis wat hulle teen die Seun van God en die kerk opstel. Daar bestaan ongeveer 48 verwysings na eksorsie in die sinoptiese Evangelies en Handelinge 6 (Sorensen, 2002:122). Dit is opvallend dat wanneer die evangeliste en Handelinge oor demone berig, dit deurgaans met demoonbestenheid in verband staan.

Konflik met bose magte word sowat vyftig keer in die Evangelies alleen beskryf (Leahy, 1990:78). Hoewel Johannes in sy evangelie nie melding maak van die demoniese binding en bevryding nie, deel dié evangelie wel die oorkoepelende visie van sataniese mag met die sinoptiese Evangelies (Joh. 7:20; 8:48-52; 10:20, 21).

Dit is duidelik dat die Evangelies eens is oor die realiteit van die duiwel en demoniese aktiwiteite. Die evangeliste gebruik ' $n$ aantal

6 Die aantal kan ongeveer halveer word wanneer parallelle tussen die Evangelies en doublette in ag geneem word. 
uitdrukkings om demoonbesetenheid te beskryf (vgl. Joubert, 2000:196; Page, 1995:138; Theron, 2003:199)7:

- Die algemene uitdrukking wat gebruik word is die werkwoord

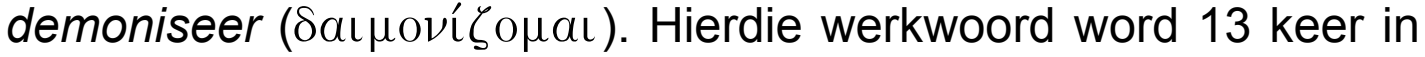
die Evangelies gebruik (bv. Matt. 4:24).

- 'n Ander uitdrukking wat gebruik word, is om 'n demoon te hê ('́X $\chi \in \mathrm{L} \nu)$ (bv. Matt. 11:18).

- Die uitdrukking word ook gebruik dat 'n demoon in ('€́v) 'n persoon is. Twee tekste berig dat 'n persoon in ('€v) 'n bose gees is (bv. Mark. 1:23). Hierdie is waarskynlik 'n Semitisme, met die gevolg dat $\hat{\epsilon} v$ eerder met met vertaal moet word.

- Daar word ook geskryf dat baie demone in iemand ingegaan het $(\epsilon i \sigma \hat{\eta} \lambda \theta \in \nu$... $\epsilon i s)$ (bv. Luk. 8:30).

- Dikwels word die uitdrukking gebruik dat demone uitgedryf word

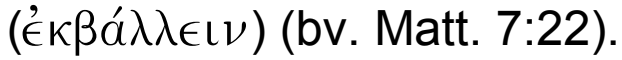

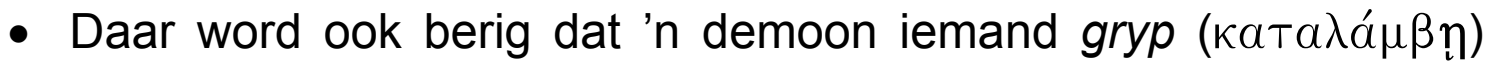
(Mark. 9:18) of pak ( $\lambda \alpha \mu \beta a ́ \nu \in \mathrm{l}$ ) (Luk. 9:39).

Uit die veelvuldige verwysing na demone en die beskrywing van die verskeidenheid aktiwiteite van demone, is dit onmiskenbaar dat die evangeliste die bestaan van duiwelbesetenheid as 'n harde en wrede werklikheid beskou het. 8 Hoewel daar binne histories-kritiese ondersoeke heelwat bedenkinge oor die historiese geloofwaardigheid van die detail van die narratiewe bestaan (cf. Twelftree, 1993:130), blyk dit uit deeglike navorsing dat berigte dat Jesus demone uitgedryf het deur verskeie onafhanklike lae van die Evangelie-tradisie bevestig word. "Taking everything into consideration, there is no reason to doubt the historical fact of exorcistic activity of Jesus" (Strecker, 2002:118). "It would be flying in the face of the evidence and a grave abuse of the historicalcritical method to dispute the essential historicity of the Gospel

7 Vergeer (2002:378-382) bied 'n oorsig van uitdrukkings wat in die Nuwe Testament as geheel gebruik word om die verskillende invloede op die lewens van mense te beskryf.

8 Davies (1995:91 e.v.) toon parallelle tussen die eksorsieverhale van Jesus in die Evangelies en ander berigte van eksorsie uit die destydse samelewing. Volgens hom moet die "werklikheid" van Jesus se eksorsies verklaar word in terme van destydse eksorsiese tegnieke, kulturele gebruike en bygelowe. 
narratives which depict Jesus as a successfull exorcist" (Dunn \& Twelftree, 1998:176).

\section{Onderskeid tussen demoonbesetenheid en siektes en gestremdhede}

Die fisiese manifestasie van besetenheid word in die Nuwe Testament beskryf as waansin, bo-natuurlike krag, woede, epilepsie, gebrekkige spraak, stomheid, doofheid en blindheid. Die kritiese vraag kan gevra word of mense in die tyd van die Nuwe Testament nie bloot alle vorme van onverklaarbare siektes aan demoonaktiwiteit toegeskryf het nie (vgl. Davies, 2995:99; Du Plessis, 2005:168). Twelftree (1993:55) praat by geleentheid van "a blurring of the distiction between healing and exorcism".

Die afleiding dat onverklaarbare siektes destyds bloot aan die invloed van bose geeste toegeskryf is, is onwaarskynlik (vgl. Leahy, 1990:79; Vergeer, 2002:374). Dit is waar dat mense wat demoonbesete was, in sommige gevalle soortgelyke simptome as ander siektes of gestremdhede vertoon het. 'n Mens moet erken dat die onderskeid inderdaad soms nie direk sigbaar was nie - wat dus die kompleksiteit van die argument illustreer. Tog blyk dit dat die simptome van besetenheid gewoonlik van 'n ernstiger aard was en onderskeidelik genoem is.

- Duiwelbesetenes praat op 'n manier wat vreemd is aan gewone siekes. Van die besetenes van Gadara berig Matteus: "Skielik het hulle begin skreeu: "Wat het $U$ met ons te doen, Seun van God? Het U hierheen gekom om ons voor die tyd te pynig?"' (Matt. 8:29). Soortgelyk berig Markus van die besetene van Kapernaum uit wie die bose geeste geskreeu het: "Wat het ons met $U$ te doen, Jesus van Nasaret? Het U gekom om ons te verdelg? Ek weet goed wie $U$ is; $U$ is die Heilige van God!"

- Duiwelbesetenes beskik oor buitengewone krag. Die besetene van Gerasa kon nie met kettings vasgebind word nie, aangesien hy telkens die voet- en handboeie uitmekaar geruk en stukkend geskop het (Mark. 5:3-4). Die man met die bose gees het die sewe seuns van Skeva oorweldig, omdat hy te sterk was vir hulle. Die gevolg is dat hulle kaal en stukkend geslaan was en moes wegvlug (Hand. 19:16).

- Daar word nie deur omstanders melding gemaak van 'n geestesversteuring by die stom man vir wie Jesus van die mag van die duiwel bevry het nie (Matt. 9:32). Dieselfde geld vir die 
blinde en stom man wat deur Jesus genees is (Matt. 12:22). Tog berig Matteus dat albei demoonbesete was.

- In Markus 9:17-18 en Lukas 9:39 word simptome wat soos epilepsie lyk aan demoniese aktiwiteite toegeskryf.

- Matteus 17:15-18 berig van 'n geestelik versteurde seun wat dikwels in vuur of water geval het.

Dit blyk ook dat die evangeliste self 'n onderskeid tref tussen gewone vorme van siekte en siekte wat simptomaties is van iets meer sinister:

- Volgens Markus 1:32 het die mense al die siekes en onderskeidelik diegene wat in die mag van die duiwels was, na Jesus toe gebring. In vers 34 word berig dat Hy baie siekes wat allerhande kwale gehad het, gesond gemaak het en (onderskeidelik) ook baie demone uitgedryf het. ${ }^{9}$

- Matteus 8:16 berig ook dat Jesus by geleentheid die geeste met 'n woord uitgedryf het en onderskeidelik al die siekes gesond gemaak het.

- Matteus 4:24 onderskei selfs tussen gewone geestelike versteuring en diegene wat in die mag van duiwels was.

- Die Evangelies berig van talle mense wat aan gebreke soos doofheid, stomheid en blindheid gely het, maar nie van die duiwel besete was nie (bv. Mark. 7:32).

Hierbenewens beredeneer Theissen (1983:85) dat berigte van eksorsie en gesondmaking in die Jesustradisies van mekaar onderskei moet word as onafhanklike genres met elk hul eie motiewe. Strecker (2002:121) stel die verhouding tussen siekte en besetenheid pertinent: "Posession in the world of the New Testament is not a disease per se. On the contrary, certain diseases are looked upon as possible indications of possession."

Voorts is dit belangrik om daarop te let dat sommige besetenes volgens die Evangelies openlik erken dat hulle van die duiwel besete is: "Jesus het vir hom gesê: 'Bose gees, gaan uit die man uit!' Hy het hom gevra: 'Wat is jou naam?' 'My naam is Legio,' exorcism and healing that subsequent authors either failed to recognize or sought to blur. In contrast, Matthew and Luke-Acts occasionally use verbs of healing ... to describe the activity of expelling demons". 
antwoord hy Hom, 'want ons is baie'" (Mark. 5:8-9). Hoewel die besetene die instrument van die demone geword het, is dit die demoon self wat hier aan die woord is, en nie die besetene nie.

Die Evangelies berig ook dat naasbestaandes van demoonbesetenes dit as sodanig erken het: "'n Kanaänietiese vrou wat in daardie gebied gewoon het, het onverwags by Hom aangekom. Sy het aanhoudend geroep: 'Ontferm U oor my, Here, Seun van Dawid! My dogter is in die mag van 'n duiwel en dit gaan sleg" (Matt. 15:22).

Dit is daarom ' $n$ twyfelagtige afleiding om te beweer dat die verskynsel van demoonbesetenheid bloot 'n bygelowige manier was om die oorsaak van allerlei siektes, gebreke of versteurings te verklaar. Op grond van 'n noukeurige histories-kritiese ondersoek kom Dunn en Twelftree (1998:178) tot die gevolgtrekking "by no means all illnesses were attributed to demons and demonpossession". Markus maak 'n duidelike onderskeid tussen siektes en besetenheid, hoewel die onderskeid by Matteus en LukasHandelinge soms meer vaag is (Sorensen, 2002:136).

\section{Voorbeelde van demoonuitdrywing in die Evangelies}

Volgens die Evangelies het demoonuitdrywing 'n wesenlike deel van Jesus se optrede uitgemaak. Hollenbach (1981:568) toon aan dat "quantitavely the exorcism played a large role in Jesus' career", "qualitatively ... exorcism figured prominently in Jesus' own understanding of his career" en "it was in connection with this particular activity that he drew upon himself the wrath of all the important public authorities of his time". Dunn en Twelftree (1998:171) skryf: "There can be no doubt that Jesus had the reputation of a successful exorcist."

In die Evangelies word sewentien keer vermeld dat mense onder die invloed van bose geeste gekom het (vgl. Dickason, 1987:34-36). Sommige van hierdie verwysings dui net aan dat Jesus baie van hierdie mense gehelp het (bv. Matt. 8:16; Mark. 1:32 en Luk. 4:41). Vyf voorvalle van demoonuitdrywing deur Jesus word in die sinoptiese Evangelies uitgebreid beskryf. 10

- Die besetene in die sinagoge van Kapernaum (Matt. 1:23-28; Luk. 4:33-37); 
- Die besetene(s) van Gadara/Gerasa (Mark. 5:1-20; Matt. 8:28-34; Luk. 8:26-39);

- Die Kanaänitiese dogter wat demoonbesete was (Mark. 7:24-30; Matt. 15:21-28);

- Die geestelik versteurde seun (Mark. 9:14-29; Matt. 17:14-21; Luk. 9:37-42); en

- Die man wat blind en stom was vanweë demoonbesetenheid (Matt. 9:32-34; Luk. 11:14 - Matt. 12:22-23 verwys moontlik na dieselfde gebeurtenis).

Die eerste twee van bogenoemde voorbeelde van besetenheid word vervolgens as voorbeelde ondersoek om elemente en eienskappe van Jesus se manier van demoonuitdrywing te identifiseer. ${ }^{11}$

\section{Die besetene in die sinagoge van Kapernaum (Mark. 1:23-28; Luk. 4:33-37)}

Volgens die Evangelies het die eerste konfrontasie tussen Jesus en demone in 'n sinagoge plaasgevind. Jesus was besig om in die sinagoge van Kapernaum op te tree. Sy gehoor was beïndruk met sy leer, want $\mathrm{Hy}$ het hulle geleer soos een wat gesag het en nie soos die skrifgeleerdes nie.

\subsection{Konfrontasie deur die besetene}

Onder hierdie gesagvolle prediking het die besetenheid van iemand in die skare aan die lig gekom. lemand wat deur 'n bose

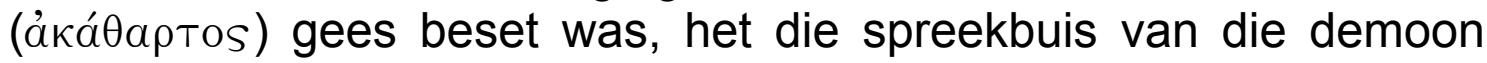
geword. Die feit dat hier nie van 'n demoon gepraat word nie, mag dui op 'n Semitiese oorsprong van die verhaal. Die uitdrukking is egter karakteristiek van Markus om die demoniese aard van die man se toestand mee te beskryf (Twelftree, 1993:60). Dit blyk dat dit nie die man self was nie, maar die bose gees wat deur die man gepraat het. "The nature of demon possession is such that the evil spirit overrides the personality of the individual he possesses, so that he can control what the person says and does" (Page, 1995:141).

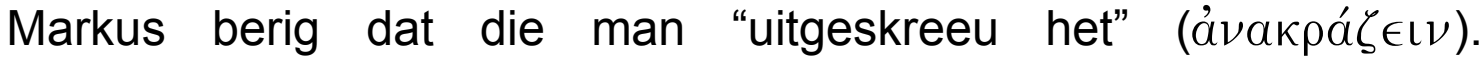

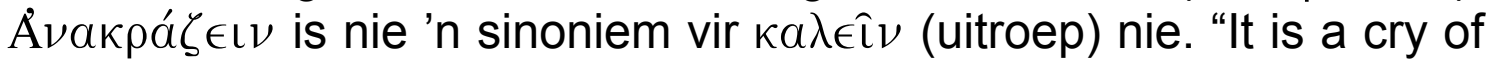


extreme consternation" (Twelftree, 1993:60). Die bose gees het op Jesus geskreeu: "Wat het ons met $U$ te doen, Jesus van Nasaret? Het $U$ gekom om ons te verdelg? Ek weet goed wie $U$ is; $U$ is die Heilige van God" (Mark. 1:24). Uit Markus en Lukas blyk die kontras tussen die "bose gees" en die "Heilige van God".

Die eerste deel wat die demoon geskreeu het, was 'n retoriese

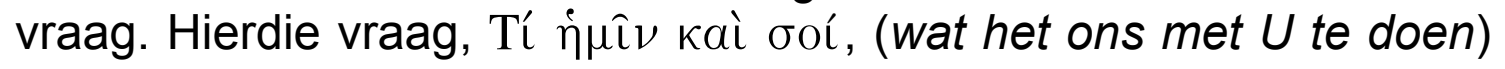
word dikwels in die Bybel gebruik in die konteks van konflik. Die uitdrukking kom ooreen met 'n Hebreeus-Aramese idioom wat in 2 Samuel 19:22, 1 Konings 17:18 en Rigters 11:12 gebruik word. In elk van dié gevalle het die uitdrukking te doen met die afweer van kwaad (Baurnfeind, 1927:6). Die bose gees het hierdie woorde uitgeroep "as a warding off of Jesus the enemy-exorcist" (Twelftree, 1993:64).

Die tweede wat die demoon geskreeu het, kom in die vorm van 'n

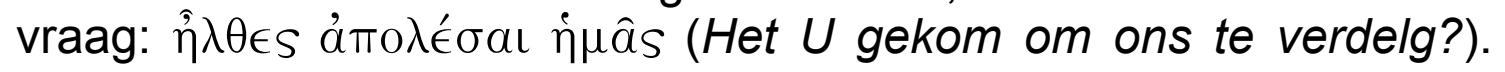
Hierdie vraag is betekenisvol. Dit dui daarop dat die demoon daarvan bewus was dat Jesus se missie die verdelging van die demoniese koninkryk ingesluit het. Hierdie woorde dui ook daarop dat die eksorsie wat Jesus binnekort sou uitvoer, nie slegs 'n daad van welwillendheid teenoor die mens was wat onder die demoon gely het nie, maar deel vorm van die kosmiese stryd tussen Jesus en die bose magte. Die verwysing na Jesus se koms, het klaarblyklik nie net betrekking op Jesus se koms na die betrokke sinagoge toe nie, maar die koms van Jesus na die aarde met 'n bepaalde missie, wat die verdelging van die demoniese ryk insluit (Van Bruggen, 1988:57). Opvallend is ook dat die demoon nie net ontsteld is oor die feit dat hy uit die man uitgedryf sal word nie - sy ontsteltenis gaan oor veel meer. Hy besef sy finale straf is voorhande. Hierbenewens verwoord die demoon ook nie net die vyandskap tussen die demone en Jesus nie, maar erken ook Jesus se volkome gesag oor hulle. Die moontlikheid dat die demone Jesus kon uitoorlê of teenstaan, is buite die kwessie.

Uit die derde deel van die demoon se woorde blyk dat hy besef het

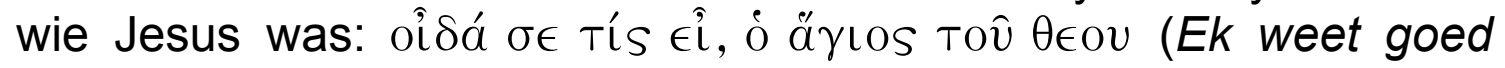
wie $U$ is; $U$ is die Heilige van God). Een van die uitstaande kenmerke van eksorsieverhale in die Evangelies is die konfessionele stellings van die demone, wat ver uitstyg bo wat gewone mense van Hom gesê het (Mc Casland, 1944:36). Die demoon se konfessionele stelling identifiseer Jesus met God en plaas Jesus in die teenoorgestelde kamp as die gees, "who is 'unclean' rather than 'holy'” (Page, 1995:142). 


\subsection{Tegniek waarvolgens Jesus die demoon uitgedryf het}

Jesus se reaksie op die woorde van die demoon was skerp: "Maar Jesus het hom skerp aangespreek: "Bly stil, en gaan uit hom uit"'

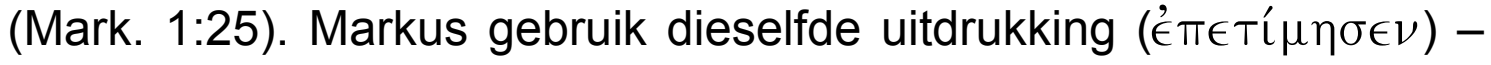
(skerp aanspreek) om die manier te beskryf waarop Jesus die storm stilgemaak het (Mark. 4:39). Dit dui op 'n uitdrukking van gesag oor die bose gees en die see. Kee (1968:232) toon aan dat die woord

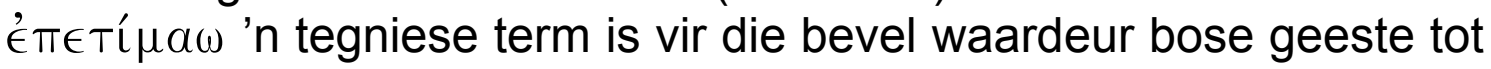
onderworpenheid gedwing word. Die term toon dat Jesus gesag het oor die bose geeste en dat hulle magteloos is om hulle teen sy beheer te verset.

Die bevel van Jesus bestaan uit twee dele: Jesus maak die demoon stil en Hy gee hom opdrag om uit die man uit te gaan. Deurdat Jesus die demoon stilgemaak het, bewys Hy sy gesag oor die bose gees. Nadat Hy die demoon beveel het om stil te bly, gee Hy die eenvoudige opdrag dat hy uit die man moet uitgaan. Jesus wend geen poging aan om die demoon op sy naam te identifiseer nie en beroep Hom op geen hoër gesag om die demoon uit te dryf nie. Hy gebruik geen magiese formule (in teenstelling met Davies [1995:98] se argumente) of materiaal soos wat dikwels in buite-Bybelse verhale van eksorsie genoem word nie (Page, 1995:144; Sorensen, 2002:137).

Mark's austere descriptions set Jesus' technique in contrast, perhaps deliberately so, with the elaborate methods known to have existed for other exorcists outside the New Testament (Sorensen, 2002:136).

\subsection{Die reaksie op Jesus se bevel}

Die volgende deel van die verhaal handel oor die reaksie op Jesus se bevel, eers deur die demoon en dan deur die skare.

Markus en Lukas berig die manier waarop die bose gees uit die man uitgegaan het. Markus plaas groter klem op die geweld waarmee dit gepaard gegaan het. Die demoon het die man stuiptrekkings laat kry en het hard geskreeu (die geskreeu word net deur Markus vermeld), maar die man was uiteindelik bevry. "The violance may have been a vehicle for dramatizing and heightening Jesus' authority" (Twelftree, 1993:71). Lukas vermeld dat die man nie beseer is nie. Die stuiptrekkings was waarskynlik die demoon se laaste poging om die slagoffer kwaad aan te doen, maar Lukas berig dat hy nie daarin kon slaag nie. Ten spyte van sy bose poging, was die demoon geheel en al ondergeskik aan Jesus se gesag. 
Die laaste element in die verhaal is die beskrywing van die reaksie van die omstanders (Mark. 1:27-29; Luk. 4:36-37). Volgens Markus was die omstanders verbaas oor wat gebeur het en het onder mekaar geredeneer: "Wat gaan hier aan? Dit is 'n nuwe leer, en dit kom met gesag! Hy gebied selfs die bose geeste, en hulle gehoorsaam hom" (Mark. 1:27). Die leer waarna hier verwys word, is klaarblyklik nie net die woorde waarmee Jesus die bose gees aangespreek het nie, maar ook sy leer wat daartoe gelei het dat die bose gees aan die kaak gestel is (Mark. 1:21-23). Die gesagvolle prediking van Jesus saam met die gesagvolle aanspreek van die bose, het daartoe gelei dat die bose gees ontbloot en uiteindelik uitgedryf is. Die omstanders erken dat die leer van Jesus nuut is. Daar was nie 'n ander leer waardeur sodanige gesag uitgeoefen kon word nie. Lukas berig oor die reaksie van die omstanders: "Wat vir 'n woord is dit dat Hy met gesag en mag die bose geeste gebied, en hulle gaan uit?" (Luk. 4:36). Die gesag van Jesus se prediking

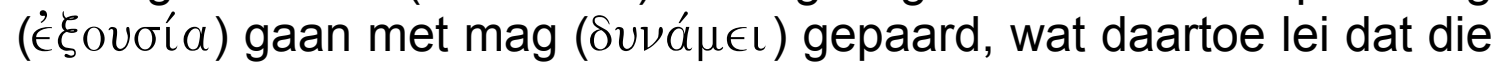
geeste Hom gehoorsaam. 12 Klaarblyklik was die omstanders nie verbaas oor die demoonuitdrywing as sodanig nie, aangesien praktyke van demoonuitdrywing nie vir hulle vreemd was nie. Die mense se verbasing spruit dalk eerder uit die feit dat Jesus eksorsie bewerk het deur 'n eenvoudige bevel, sonder die rituele wat destyds in gebruik was. Guijarro (2002:175) ontwerp 'n model waarvolgens hy die reaksie van die skare13 binne sosio-politieke konteks verklaar. Die toepassing van die model op hierdie konteks lyk egter geforseerd.

Hierdie vertelling neem 'n prominente plek in by Markus en Lukas, aangesien dit in albei gevalle die eerste wonder is wat opgeteken is. Albei hierdie Evangelies koppel die uitdrywing deur Jesus aan die gesagvolle prediking van Jesus. "The scene in the synagogue is programmatic of Jesus' ministry of teaching and healing" (Page, 1995:139). "We can probably say that this narrative, ... being placed first in the public ministry of Jesus, is paradigmatic and programmatic for his (Mark's) story of Jesus" (Twelftree, 1993:57). Sowel Markus as Lukas berig ook dat nadat Jesus die sinagoge verlaat het, Hy Petrus se skoonma genees het (Mark. 1:29-31; Luk. 4:38-39), en dat Hy in die aande baie mense wat demoonbesete of

12 Volgens Davies (1995:93-98) spruit hierdie vertelling uit 'n uitgediende dichotomistiese beeld van die bo-natuurlike, naamlik van 'n almagtige God wat demone toelaat, maar wat tog aan Hom ondergeskik is.

Hy onderskei tussen magnification, manupilation en obliteration. 
siek was, genees het. "The exorcism in the synagogue plays a major role in what appears to be represented as a typical day in the ministry of Jesus" (Page, 1995:139).

Markus en Lukas plaas hierdie vertelling kort na hulle berigte van Jesus se versoeking in die woestyn. In Markus word slegs die roeping van die eerste vier dissipels tussen die vertellings gevoeg (Mark. 1:14-20) en in Lukas slegs Jesus se prediking in die sinagoge in Nasaret (Luk. 4:14-30). Deur die berigte van die versoeking in die woestyn en die eksorsie kort na mekaar te plaas, toon die evangeliste aan dat Jesus se mag oor die geestesryk die konsekwensie is van sy oorwinning oor die duiwel in die woestyn.

\section{Die besetene(s) in Gadara/Gerasa (Mark. 5:1-20; Matt. 8:28-34; Luk. 8:26-39)}

Die berig oor die besetene(s) van Gadara/Gerasa bied die mees uitbreide beskrywing van eksorsie in die Nuwe Testament. Al drie die sinoptiese Evangelies beskryf die gebeurtenis, en in al drie gevalle volg dit op die beskrywing van Jesus wat die storm op die see stilgemaak het (Matt. 8:23-27; Mark. 4:35-41; Luk. 8:22-25). Terwyl Jesus en sy dissipels oor die see gevaar het, het hulle 'n skrikwekkende storm meegemaak. Jesus het dit egter met 'n mondelinge bevel stilgemaak. Toe hulle aan die ander kant van die meer kom, is Jesus (en die dissipels) deur die besetene(s) gekonfronteer. Dit is duidelik dat al drie die evangeliste hierdie twee gebeurtenisse kronologies en tematies aan mekaar verbind. "Op de bedwogen zeebeving (Matt. 8:26) volgt nu een dreiging voor de weg over land" (Van Bruggen, 1990:153). Albei verhale berig oor Jesus se gesag oor vyandige en lewensgevaarlike magte.

Hier word nie in detail ingegaan op die probleem dat Matteus van twee besetenes berig, terwyl Markus en Lukas net van een praat nie. Ook word hier nie ondersoek waarom Matteus berig dat die genesing in die land van die Gadareners plaasgevind het, terwyl Markus en Lukas berig dat dit in die landstreek van Gerasa14 plaasgevind het nie. 15 Moontlik was daar twee besetenes waarvan een na vore gekom het. Hy was moontlik ook die mees vreesaanjaende van die twee. Die voorkoms van die besetene was

14 Vgl. Van Bruggen (1988:121 \& 1990:153) se bevredigende bespreking van die vraagstukke oor een of meer besetenes en van die plekname. 
in elk geval verskriklik. Elkeen van die evangeliste het sy eie manier om dit te stel. Markus se beskrywing is baie grafies. Die besetene het nakend tussen die grafte gebly. Volgens Joodse (by-)geloof het bose geeste veral in die woestyn en tussen grafte rondgeswerf (Leahy, 1990:81; Page, 1995:151). Hierbenewens toon Hagner (1993:227) aan "'coming out of the tombs' suggests not merely the ritually unclean place where the demoniacs lived but the close association of such possession with death and the powers of evil". Die besetene het 'n tragiese gewelddadige lewe gely. Hy het gereelde uitbarstings en vertoon van buitengewone krag gehad. Die besetene se hele persoonlikheid is deur die bose geeste beheers, wat van hom 'n wandelende maniak gemaak het. Hy was 'n gevaar vir homself en vir ander mense. Sy individualiteit is onderdruk, met die gevolg dat hy die instrument van die folteraars geword het (Sorenson, 2002:124).

Hierdie verhaal vertoon 'n aantal eienskappe wat nie by ander berigte van die evangeliste oor eksorsie voorkom nie. Dit is byvoorbeeld die enigste berig dat Jesus se aanvanklike bevel nie regstreeks effektief was nie. Verder doen Jesus ook navraag na die demoon se naam en Hy staan die versoek toe van die demone om in die varke in te vaar.

\subsection{Konfrontasie deur die bose geeste}

Die sinoptiese Evangelies se berigte lui dat die besetene Jesus direk nadat $\mathrm{Hy}$ aan wal gegaan het, tegemoet gegaan het. Die besetene het die inisiatief geneem om kontak met Jesus te maak. Toe die besetene vir Jesus sien, het hy nader gehardloop en voor Hom neergeval ( besetene uiters ontsteld was om Jesus te ontmoet. Hy het met 'n harde stem $(\phi \omega \nu \hat{\eta} \mu \epsilon \gamma a ́ \lambda \eta)$ uitgeskreeu (Mark. 5:6). Hierdie geskreeu stem ooreen met die ávaкpá $\zeta \in \mathrm{L} \nu$ van die besetene in die sinagoge van Kapernaum - 'n desperate uitroep van uiterste konsternasie.

Vier frases word genoem wat die demoon se woorde aan Jesus weergee. Die eerste is: "Wat het U met my te doen". Soortgelyk as in Markus 1:24 moet hierdie woorde verstaan word as defensiewe aksie teen die dreigende eksorsis.

Tweedens noem die demoon Jesus op die Naam. Volgens Markus 5:7 en Lukas 8:28 is die titel waarmee die besetene Jesus 
aangespreek het viè Tov̂ $\theta \in o \hat{~ T o v ̂ ~ v ̛ \psi i ́ o t o v ~(S e u n ~ v a n ~ d i e ~}$ allerhoogste God). Matteus 8:29 praat slegs van Seun van God.16 Die titel klink vreemd uit die mond van die demone. Sommige navorsers lei hieruit af dat die woorde deel was van Markus se weergawe of ten minste 'n byvoeging van die vroeë kerk. Twelftree (1993:82) toon egter aan dat "since demons were believed to include the character and origin of their opponents in their defence, it may be concluded that it is unlikely that the early Church needed to introduce 'Son of God' here". Uit die titel blyk dat die demone nie anders kon as om die gesag van Jesus te erken nie. "The demons here ... sense immediately the identity of Jesus ... and know at once that their realm is fundamentally threatened by his presence" (Hagner, 1993:227).

Hierna volg die derde frase in die demoon se woorde van verdediging. Volgens Markus 5:7 is die inleidende woorde van die demoon aan Jesus ó $\kappa_{i} \zeta \omega \sigma \in(E k$ smeek u/Ek besweer $U)$. Dit was blykbaar gebruik by eksorsiste om die naam van 'n godheid aan te roep en van hierdie werkwoord gebruik te maak wanneer hulle iemand van 'n demoon wou bevry (Page, 1995:151; vgl. Hand. 19:13). Ironies genoeg was dit juis die demoon wat die uitdrukking in hierdie geval gebruik het. So sou die demoon probeer "to be using God as his source of power-authority to fetter Jesus" (Twelftree, 1993:83). Met hierdie formule het die demoon Jesus gesmeek om hom nie te pynig nie, aangesien die demoon besef het dat Jesus vir hom gevaar inhou. Die demoon se vrees getuig van Jesus se gesag oor die demoniese ryk. Dit is egter opvallend dat Jesus nooit hierdie formule gebruik nie. Hy tree met eie gesag op.

Die laaste deel van die woorde van die demoon was: Moet my nie pynig nie (Mark. 5:7 e.v.), want Jesus het die bose gees beveel om uit die man uit te gaan (Mark. 5:8). Die bose geeste het Jesus onmiddelik as die Seun van God herken en besef dat hulle verdoem is en dat hulle die bevel van Jesus nie kon weerstaan nie. Die demoon probeer nogtans om die bedreiging van Jesus as eksorsis af te weer.

\subsection{Jesus vra die naam van die demoon}

Markus 5:9 en Lukas 8:30 berig dat Jesus die naam van die demoon gevra het. Dit is die enigste plek in die Evangelies dat Jesus dit 
gedoen het. Dit is ook die enigste keer dat Jesus in gesprek met 'n demoon getree het. Blykbaar het mense destyds geglo dat as iemand die naam van die demoon geken het, hy mag oor die demoon kon uitoefen (Page, 1995:152; Sorensen, 2002:130; Twelftree, 1993:84). Dit is egter onwaarskynlik dat dit die rede was waarom Jesus die demoon om sy naam gevra het (soos Davies, 1995:92 aanvoer). Eksorsiste het gewoonlik baie gesukkel om die demone te dwing om hulle name te verklap, aangesien dit hulle weerloos sou laat. Jesus het egter geen probleem daarmee gehad nie, aangesien die demoon blykbaar onmiddelik sy naam gegee het. Volgens al die ander berigte in die Evangelies blyk dit dat Jesus geheel en al in beheer was oor demone en dat Hy nie hulle name nodig gehad het om beheer oor hulle uit te oefen nie. Jesus se vraag na die naam van die demoon was waarskynlik eerder bedoel om daarmee die verskriklike toestand van die besetene te beklemtoon. Dit was 'n baie ernstige geval van besetenheid.

In antwoord op Jesus se vraag het die demoon geantwoord: "My naam is Legio ... want ons is baie" (Mark. 5:9; Luk. 8:30). Die demoon gee nie sy naam as sodanig nie, maar toon aan dat hulle baie is. ' $n$ Romeinse legioen het gewoonlik uit 6000 man bestaan. In 'n landstreek wat deur Romeine beset is, was legioen 'n paslike term om die groot aantal demone mee te beskryf. 17 Die naam moet waarskynlik idiomaties verstaan word om aan te toon dat die man deur 'n baie groot aantal demone besete was. 18 "History of religion parallels show that it was important not only to know the name and how it related to the nature of the demon, but also the actual nature of the demon" (Twelftree, 1993:85). Die frase want ons is baie verwys moontlik na hierdie gebruik.

\subsection{Onderhandelinge van die demoon}

Die evangeliste berig hierna van die varke wat die see ingestorm het. Heelwat navorsers meen dat hierdie 'n tweede verhaal is wat aan die eerste gelas is. Die eerste verhaal sou oor eksorsie handel en die tweede oor die vernietiging van die trop varke. Twelftree

17 Sommige verklaarders lei uit die naam in politieke en sosiale bedoeling van die verhaal af. "Legion' symbolizes the Roman occupation of Judaea and its environs" (Sorenson, 2002:130).

18 Daar bestaan ook ander verwysings in die Evangelies na meervoudige demoonbesetting: Maria Magdalena was deur sewe demone beset (Luk. 8:2); die gelykenis van die rustelose demoon in Matteus 12:43-45 en Lukas 11:24-26 en die intrek van agt demone in die man wat voorheen bevry sou wees. 
(1993:74) toon egter op grond van historiese oorwegings aan dat so 'n tweedeling onwaarskynlik is. Sowel in Babiloniese, Griekse en Romeinse tradisies is daar geglo dat bose geeste van persoon tot persoon en van persone na objekte oorgedra kon word. "The demons were believed to have passed from the man to the pigs and then, possibly, from the pigs to their watery home" (Twelftree, 1993:75). "Water was understood as one of the appropriate havens of demons" (Twelftree, 1993:86).

Die feit dat die demone gesmeek het om in die varke te kon invaar, was aan die een kant "een capitulatie-voorstel" (Van Bruggen, 1988:121), maar waarskynlik ook 'n poging om die vervloeking van Jesus vry te spring. Hierdie onderhandeling van die demoon met Jesus is opvallend, aangesien die ander eksorsieberigte daarop dui dat die demone onmiddelik vir Jesus gehoorsaam het en gewyk het. Die evangeliste berig nie waarom Jesus aan die demone se versoek voldoen het nie. Waarskynlik was dit om duidelik te maak dat die wrede besetenheid van die man tot 'n end gekom het. Wat wel duidelik is, is dat die versoek nie tot voordeel van die demone toegestaan is nie.

Deurdat die demone in die varke wou invaar, word die afbrekende mag van die demone beklemtoon, tesame met hulle begeerte om te benadeel en te beseer. Daar is al heelwat gespekuleer oor hierdie gebeure. Hieruit word dikwels afgelei dat demone een of ander vorm van fisiese kontak verlang om van hulle ellende te ontvlug (Leahy, 1990:83). Dit is egter eerder logies dat hulle hierdie fisiese kontak soek om diegene waarin hulle hulle intrek neem, te benadeel in hulle absolute vyandigheid teenoor God en sy skepping. Dit is waarskynlik dat hulle in die varke wou intrek om verskrikking te wek en die eienaars daarvan vyandig teenoor Jesus te stem. Die houding van die varkeienaars as sodanig teenoor Jesus word nie berig nie. Wat wel duidelik is, is dat Jesus die behoud van die man belangriker geag het as dié van die trop varke.

$\mathrm{Na}$ afloop van die dramatiese gebeure is dit duidelik dat die man geheel en al genees is. Hy sit by sy volle verstand by Jesus, sy Bevryder. Hy is geklee en tree sosiaal normaal op. Al wat oorbly is dat hy aan die mense moet gaan vertel wat die Here alles vir hom gedoen het. Anders as mense van die gemeenskap wat wou gehad 
het dat Jesus moes weggaan, 19 het die man wat bevry is, gesmeek om saam met Jesus te gaan (Matt. 8:35; Mark. 5:17-18; Luk. 8:3738). Jesus staan sy versoek egter nie toe nie, maar gee hom opdrag om aan sy mense te gaan vertel wat Jesus vir hom gedoen het.

\section{Kenmerke van demoonuitdrywing}

Uit die twee voorbeelde kan 'n aantal kenmerke geïdentifiseer word, wat met Jesus se demoonuitdrywing gepaard gegaan het.

\subsection{Karakter van die besetenes}

Die besetene in die sinagoge van Kapernaum het ' $n$ bose gees gehad. Uit die beskrywing blyk dit dat die persoon vooraf geen simptome getoon het dat hy deur 'n bose gees beset was nie. Hy was deel van die normale samelewing en het selfs aan die godsdienstige lewe van die gemeenskap deelgeneem.

Hierteenoor vertoon die besetene(s) van Gerasa/Gadara 'n totaal ander karakter. Hy/hulle het op die rand van die samelewing gewoon, tussen die grafte. Die feit dat hy/hulle dag en nag aan die skreeu was en hom/hulself met klippe gekap het, kan dui op klaagrites wat handuit geruk het. Die besetene(s) was gewelddadig en kon nie onder beheer gebring word nie. Pogings om hom/hulle voorheen onder beheer te bring, kan dui op vorige pogings wat aangewend is om die bose uit hom/hulle te dryf.

\subsection{Dramatiese konfrontasie as Jesus verskyn}

Toe die besetene Jesus in die sinagoge van Kapernaum ontmoet, het hy uitgeskreeu, waaruit dit onmiddellik geblyk het dat hy besete is. Die besetene(s) van Gerasa/Gadara het voor Jesus neergeval en ook geskreeu. Sodra die besetenes Jesus teëgekom het, het dit telkens tot dramatiese en ontstellende konfrontasie gelei.

\subsection{Wanhopige uitsprake van die besetenes}

In albei die voorbeelde uiter die besetenes hulle wanhoop in die aanvanklike konfrontasie met Jesus. Met hulle woorde het hulle te kenne gegee dat Jesus in die sfeer van God verkeer, veral in sy hantering van die bose geeste. Hulle het besef dat Hy met krag van

19 Guijarro (2002:165) verklaar hierdie vyandigheid deur te beweer dat Jesus daardeur die sosiale elite uitgedaag het. Om so 'n interpretasie uit die teks self af te lei, is egter geforseerd. 
God toegerus is om die bose uit te dryf. Op een of ander manier het die demone probeer om Jesus te "ontwapen" deur sy verbondenheid met God aan te dui.

\subsection{Jesus se woorde van eksorsie}

McCasland voer aan dat Jesus nie bepaalde formules gebruik het om die bose geeste uit te dryf nie. "He cast out demons by his personal command, not by means of any kind of formulae, incantations, ritual or magical objects" (Mc Casland, 1951:112). Hierteenoor meen Aune (1980:1532)

the great gulf which some New Testament scholars would place between 'the powerful word of the Son' and 'magical incantations' is simply non-existent. The short authoritative commands of Jesus to demons in the Gospel narratives are formulas of magical adjuration.

Die woorde, wat Jesus in die twee voorbeelde wat bespreek is, gebruik het, kon net so goed woorde uit 'n algemene woordeskat wees. Om op grond van hierdie twee voorbeelde alleen te wil aflei dat Jesus magiese formules gebruik het, is twyfelagtig.

\subsection{Smeking om versagting}

Die demone in die bestene(s) van Gadara/Gerasa het onderhandel vir gunstiger omstandighede. Uit buite-Bybelse gegewens $(1$ Henog 12-14 en Jubilee 10) blyk dit dat sodanige versoek van demone meermale voorgekom het.

\subsection{Oordrag van demone}

Die episode toe die demone in die varke ingevaar het en uiteindelik in die see beland het, dui op die moontlikheid van die oordrag van demone uit persone tot objekte. Die see is blykbaar beskou as 'n tuiste vir die demone.

\subsection{Geweld tydens die eksorsies}

By albei die voorbeelde wat ondersoek is, het gewelddadige dinge gebeur toe die demone uitgedryf is. Die besetene in Kapernaum het ontsettende stuiptrekkings gekry en hard geskreeu toe die uitdrywing plaasgevind het. By die bestene(s) van Gadara/Gerasa het die demone in die varke ingevaar, wat hulle daarna oor die krans in die see laat storm het. 


\section{Unieke eienskappe van Jesus se metodes}

Twelftree (1993:157 e.v.) beskryf dat magiese middele, die inroep van power-authority, gebedsformules en die besweringsformule

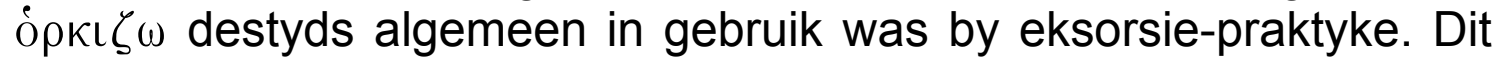
is egter opvallend dat Jesus se praktyke hiervan verskil (Sorensen, 2002:138).

Dit was gebruiklik in destydse eksorsie-tegnieke dat middels gebruik is, byvoorbeeld hare, water, takke van tamariske, potskerwe en amulette (Twelftree, 1993:156). Uit die twee voorbeelde wat ondersoek is, blyk dit dat Jesus slegs woorde gebruik het. By twee ander geleenthede toe Jesus die doofstom man (Mark. 7:33) en die blindgeborene (Joh. 9:6) genees het, het Hy wel van speeksel gebruik gemaak. Dít as sodanig dui egter nie daarop dat Jesus van middels gebruik gemaak het tydens eksorsie nie.

Eksorsiste in die tyd van Jesus "conducted their healing using a conspicious or recognizable power-authority, incantations and prayers" (Twelftree, 1993:160). Hierteenoor blyk dit dat Jesus nie 'n oproep tot 'n bron van power-authority gemaak het nie. Jesus het nie die bekende besweringsformules van destyds gebruik nie. Hy het nie gesteun op 'n mag buite Homself nie. Hy het selfs nie die naam God aangeroep soos wat 'n mens sou verwag nie!20 Die Evangeliste beklemtoon Jesus se eie gesag wanneer Hy deur die demone gekonfronteer word (Sorensen, 2002:138).

Eksorsie was blykbaar 'n gebruik onder die Jode toe Jesus na die wêreld gekom het. Dit gee daartoe aanleiding dat sommige navorsers die eksorsies van Jesus gelyk wil stel met soortgelyke pre-moderne praktyke. Davies (1995:104) skryf:

Jesus was a 'Medium' ... he was a spirit-possessed healer ... the overall parameters of his role in first-century Palestine are nothing unusual.

Tog bevraagteken Kampling (1986:247) op goeie gronde of eksorsie werklik algemeen voorgekom het. In vergelyking met die Nuwe Testament bestaan daar in buite-Bybelse bronne relatief min getuienis oor eksorsie.

20 Die Evangelies (veral Lukas) berig telkens hoe belangrik gebed vir Jesus was (Viljoen, 2004:638). 
In die lig van die onderskeid tussen Jesus se manier van demoonuitdrywing en die van die Jode, waarsku Leahy teen heidense vorms van eksorsie waardeur mense net dieper in die mag van die bose kom: "Our Lord has clearly condemned the practice of an exorcism which, by its failure to give the sufferer immunity from future demon possession, demonstrates its unsatisfactory character" (Leahy, 1990:103). Jesus se argument oor 'n bose gees wat uit 'n mens uitgegaan het, maar later weer terugkeer, toon hierdie gevaar aan:

Wanneer 'n bose gees uit 'n mens weggaan, swerf hy deur dor streke op soek na 'n rusplek. As hy dit nie kry nie, sê hy: 'Ek gaan terug na my huis waaruit ek weggegaan het' ... aan die einde is so 'n mens slegter daaraan toe as aan die begin" (Matt. 12:43-45; vgl. ook Luk. 11:24-26).

Hierin is die groot leemte van heidense praktyke van eksorsie geleë. Daar bestaan nie so iets soos 'n geestelike vakuum nie.

The main lesson is that before there can be permanent dispossession of a demon there must be a spiritual repossesion of the victim (Leahy, 1990:104).

Die wedergeboorte van die slagoffer is dus nodig. Die Heilige Gees moet so 'n mens se lewe vul. Demoonbesetenheid is 'n aaklige karikatuur van wat dit beteken dat die Heilige Gees in 'n mens woon. lemand wat deur die Heilige Gees beheer word, word met God se guns begenadig (Viljoen \& Stoltz, 2005:272). So 'n persoon is 'n nuwe mens wat in staat gestel word om God te eer en aan sy skeppingsdoel te beantwoord. In kontras hiermee kom iemand wat deur 'n demoon beset word onder beheer van die Satan. So 'n mens verander in 'n vreeslike karikatuur van wat 'n mens veronderstel is om te wees.

Uit die manier waarop Jesus demone uitgedryf het en die feit dat $\mathrm{Hy}$ aan sy dissipels opdrag gegee het om dit te doen, blyk dat demoonuitdrywing altyd plaasvind binne die konteks van die bediening van die evangelie. Die opdrag van Jesus aan sy dissipels om duiwels uit te dryf (Matt. 10:8) vorm deel van die oorkoepelende opdrag om die evangelie te gaan verkondig: "Gaan verkondig: 'Die koninkryk van die hemel het naby gekom'” (Matt. 10:7). Die bediening van die twee-en-sewentig (Luk. 10:1 e.v.) waartydens demone uitgedryf is, was in die eerste plek die bediening van die evangelie. Waar die evangelie verkondig word, is die Heilige Gees aan die werk. Waar die Heilige Gees deur die bediening van die evangelie aan die werk is, moet demoniese magte wyk. Jesus se 
opmerking: "Ek het die Satan soos 'n weerligstraal uit die hemel sien val" (Luk. 10:18) moet in dié lig verstaan word. Wanneer Jesus direk met die demone gepraat het of by monde van sy verteenwoordigers gepraat het, het sy Woord gesag gehad. Die vinger van God, die Heilige Gees, kom aan die werk en die magte van die bose vyand moet wyk.

\section{Slot}

Getuienis van demoniese aktiwiteite en allerlei bevrydingspraktyke in die huidige samelewing, maak verantwoordelike Skriftuurlike besinning oor die onderwerp noodsaaklik. Hoewel die konsep van die bose in sommige kritiese kringe as deel van 'n vergane wêreldbeeld beskou word, word binne gereformeerde kringe gewoonlik uitgegaan van die standpunt dat die duiwel en demone 'n wrede werklikheid is en nie bloot iets was waaraan onverklaarbare gedrag van mense destyds toegeskryf is nie. Die historiese getuienis van die Evangelies oor eksorsies van Jesus kan op grond van histories-kritiese oorwegings aanvaar word. Uit hierdie getuienis blyk die verhoogde aktiwiteit van die bose tydens die aardse optrede van Jesus asook die beslissende triomf van Jesus oor die bose. Hoewel eksorsie nie uniek is aan Jesus nie, blyk dit uit die Evangelies dat die manier waarop Jesus demone uitgedryf het, uniek en vir die demone onweerstaanbaar was, omdat Hy met goddelike gesag opgetree het. Uit die Evangelies kom die aard van demoonbesetenheid aan die lig en dit werp lig op die huidige pastoraat aan demoongekweldes. Deur Jesus se absolute gesag oor die duiwel en demone te demonstreer, word dit duidelik dat die Koninkryk van God gekom het.

\section{Geraadpleegde bronne}

AUNE, D.E. 1980. Magic in early Christianity. Aufstieg und Niedergang der römischen Welt, ii.23.2:1507-1557.

BAURNFEIND, O. 1927. Die Worte de Dämonen im Markusevangelium. Stuttgart: Kohlhammer.

BULTMANN, R. 1953. The New Testament and mythology. (In Bartsch, H.W., ed. Kerygma and myth. London: SPCK. p. 1-24.)

COETZEE, J.C. 1969. Satan, die sataniese magte en die sonde. (In Du Toit, S. et al., reds. Die koninkryk van God. Potchefstroom: Herald. p. 76-95.)

DAVIES, S.L. 1995. Jesus the healer: possession, trance and the origins of Christianity. New York: Continuum.

DICKASON, C.F. 1987. Demon possession and the Christian. Chicago: Moody.

DU PLESSIS, I. 2005. Jesus die keuse: eerlike geloofsvrae oor die Jesusgesprek. Wellington: Lux Verbi.BM.

DUNN, J.D.G. 2003. Jesus remembered: Christianity in the making. Volume 1. Grand Rapids: Eerdmans. 
DUNN, J.D.G. \& TWELFTREE, G.H. 1998. Demon-possession and exorcism in the New Testament. (In Dunn, J.D.G. The Christ and the Spirit: collected essays. Volume 2: Pneumatology. Edinburgh: Clark. p. 170-186.)

GIBBONS, B.J. 2001. Spirituality and the occult: from the Renaissance to the modern age. London: Routley.

GOODMAN, F.D. 1988. How about demons? Possession and exorcism in the modern world: folklore today. Bloomington: Indiana University Press.

GUIJARRO, S. 2002. The politics of exorcism. (In Stegemann, W., Malina, B. \& Theissen, G., eds., The social setting of Jesus and the Gospels. Minneapolis: Fortress. p. 159-174.)

HAGNER, D.A. 1993. Word Biblical commentary. Vol. 33A: Matthew 1-13. Dallas: Word Books.

HOLLENBACH, P.W. 1981. Jesus, demoniacs, and the public authorities: a socio historical study. Journal of the American Academy of Religion, 49:561-588.

JANSE VAN RENSBURG, J. \& CILLIERS, J.H.J. 1998. 'n Poimenetiese ondersoek na 'n basisterorie vir die pastoraat aan okkultgekweldes. Acta Theologica, 18(2):33-49.

JOUBERT, S. 2000. Is die duiwel los? Nuwe-Testamentiese perspektiewe op die stryd tussen Christus en die bose. In die Skriflig, 24(2):195-206.

KAMPLING, R. 1986. Jesus von Nazareth - Lehre und Exorzist. Biblische Zeitschrift, 30:237-248.

KEE, H.C. 1968. The terminology of Mark's exorcism stories. New Testament Studies, 14:232-246.

LANGTON, E. 1977. Satan, a portrait: a study of the character of Satan through all the ages. London: Skeffington.

LEAHY, F.S. 1990. Satan cast out: a study in Biblical demonology. Edinburgh: Banner of Truth Trust.

LOUW, J.P. \& NIDA, E.A. 1989. Greek-English lexicon of the New Testament based on semantic domains. Volume 1. Cape Town: Bible Society.

MC CASLAND, V.S. 1944. The demonic 'confessions' of Christ. Journal of Religion, 24:33-36.

MC CASLAND, V.S. 1951. By the finger of God. New York: Macmillan.

MÖLLER, F.P. 1987. Pentecostal perspectives on the activity of demonic powers. (In De Villiers, P.G.R., ed. Like a roaring lion: essays on the Bible, the church and demonic powers. Pretoria: UNISA. p. 173-191.)

OUWENEEL, W.J. 2003. Geneest de zieken! Over de bijbelse leer van ziekte, genezing en bevrijding. Vaassen: Medema.

PAGE, S.H.T. 1995. Powers of evil. Grand Rapids: Baker Books.

PILCH, J.J. 2000. Healing in the New Testament: insights from medical and mediterranean anthropology. Minneapolis: Fortress.

SORENSEN, E. 2002. Possession and exorcism in the New Testament and early Christianity: wissenschaftliche Untersuchungen zum Neuen Testament. 2. Reihe. 157. Tübingen: Möhr \& Siebeck.

STAUFFER, E. 1948. Die Theologie des Neuen Testaments. Gütersloh: Bertelsmann.

STRAUSS, D.F. 1973 [1846]. The life of Jesus critically examined. London: SCM.

STRECKER, C. 2002. Jesus and the demoniacs. (In Stegemann, W., Malina, B. \& Theissen, G., eds. The social setting of Jesus and the Gospels. Minneapolis: Fortress. p. 117-134.) 
THEISSEN, G. 1983. The miracle stories of the early Christian tradition. Philadelphia: Fortress.

THERON, J.P.J. 2003. "Beset" of "beserk"? 'n Besinning oor enkele begrippe binne die kerklike diens van bevryding van bose magte. Acta Theologica, 23(1):194-212.

TWELFTREE, G.H. 1993. Jesus the exorcist: a contribution to the study of the historical Jesus. Tübingen: Möhr/Siebeck.

VAN AARDE, A.G. 1987. Demonoly in New Testament times. (In De Villiers, P.G.R., ed. Like a roaring lion: essays on the Bible, the church and demonic powers. Pretoria: UNISA. p. 22-37.)

VAN BRUGGEN, J. 1988. Marcus: het evangelie volgens Petrus: commentaar op het Nieuwe Testament. Kampen: Kok.

VAN BRUGGEN, J. 1990. Matteüs: het evangelie voor Israel: commentaar op het Nieuwe Testament. Kampen: Kok.

VAN ZYL, H.C. 1992. Die duiwel ontmasker - 'n Nuwe-Testamentiese perspektief. Universiteit van die Vrystaat Teologiese Studies, 6:9-22.

VERGEER, W.C. 2002. Okkultiese binding en bevryding: 'n NuweTestamentiese perspektief. In die Skriflig, 36(3):369-395.

VILJOEN, F.P. 2004. Gebed in die lewe van Jesus volgens Lukas. In die Skriflig, 38(4):623-642.

VILJOEN, F.P. \& STOLTZ, H.J. 2005. Die Heilige Gees in die Evangelie volgens Lukas. Nederduitse Gereformeerde Teologiese Tydskrif, 46(1 \& 2):260-273.

\section{Kernbegrippe:}

demoon: uitdrywing

duiwelbesetenheid

eksorsie: getuienis van die Evangelies

historiese Jesus

\section{Key concepts:}

demon: deliverance

demon-possession

exorcism: evidence from the Gospels

historical Jesus 